\title{
PENGEMBANGAN PERANGKAT PEMBELAJARAN MEMBACA PEMAHAMAN MENGGUNAKAN GRAPHIC ORGANIZER PLOT DIAGRAM UNTUK KELAS VI SEKOLAH DASAR
}

\author{
Delita Gustriani \\ PGSD STKIP Rokania \\ delitagustriani@gmail.com
}

\begin{abstract}
Teachers have responsibility to create and develop an effective learning instruments in order to facilitate the student to understand the reading content optimally. Unfortunately, not all teachers are able to accept and run that responsibility. There are, it is important to develop an effective learning instruments by using Graphic Organizer Plot Diagram as the solusion. The learning instruments were developed by using 4-D model (Defining, Designing, Developing, and Disseminating). The design was validated by four experts and three educational practitioners. To see the practicality and the effectiveness of the instruments developed, it then was tried out limitedly to the students in class VI of SDN 18 Air Tawar Selatan. The disseminating phase, however, was done in a limited scale. The result of the research indicated that the validity rate into the category of highly valid. Then upon the assessment on the implementation of lesson plan, the responses from teachers and learning participants and the observations on teaching materials indicated that the practicality rate fell to the category of highly practical. Moreover, the result of the activity of learning participants on reading comprehension indicated to be effective. Based on the result of the research, it was concluded that the Graphic Organizer Plot Diagram strategy-oriented reading comprehensionlearning instruments developed had been valid, practical, and effective.
\end{abstract}

Keywords: Learning Instruments, Reading Comprehension, Graphic Organizer Plot Diagram.

\section{ABSTRAK}

Guru memiliki tanggung jawab untuk membuat dan mengembangkan instrumen pembelajaran yang efektif untuk memudahkan siswa memahami isi bacaan secara optimal. Sayangnya, tidak semua guru dapat menerima dan menjalankan tanggung jawab itu. Ada, penting untuk mengembangkan instrumen pembelajaran yang efektif dengan menggunakan Graphic Organizer Plot Diagram sebagai solusinya. Instrumen pembelajaran dikembangkan dengan menggunakan model 
4-D (Mendefinisikan, Merancang, Mengembangkan, dan Menyebarluaskan). Desain ini divalidasi oleh empat ahli dan tiga praktisi pendidikan. Untuk melihat kepraktisan dan keefektifan instrumen yang dikembangkan, kemudian diadili secara terbatas kepada siswa di kelas VI SDN 18 Air Tawar Selatan. Namun fase penyebarluasan dilakukan dalam skala terbatas. Hasil penelitian menunjukkan bahwa tingkat validitas masuk dalam kategori sangat valid. Kemudian setelah penilaian pada pelaksanaan rencana pelajaran, tanggapan dari guru dan peserta belajar dan pengamatan pada bahan ajar menunjukkan bahwa tingkat kepraktisan jatuh ke kategori sangat praktis. Selain itu, hasil dari aktivitas peserta belajar membaca pemahaman diindikasikan efektif. Berdasarkan hasil penelitian, disimpulkan bahwa Grafik Organiser Plot Diagram yang berorientasi pada strategi membaca pemahaman instrumen pembelajaran yang dikembangkan telah valid, praktis, dan efektif.

Kata kunci: Instrumen Pembelajaran, Pemahaman Membaca, Diagram Plot Grafis.

\section{A. Pendahuluan}

Penggunaan perangkat pembelajaran dalam proses pembelajaran merupakan faktor yang sangat penting dalam mengarahkan peserta didik untuk memperoleh pengalaman belajar. Tersedianya perangkat pembelajaran di sekolah untuk mata pelajaran bahasa Indonesia merupakan salah satu faktor yang dapat menunjang proses pembelajaran berjalan dengan baik.

Pembelajaran bahasa Indonesia terdiri dari empat keterampilan, yaitu: keterampilan menyimak, berbicara, membaca, dan menulis. Keempat keterampilan tersebut merupakan keterampilan yang harus dikuasai oleh peserta didik dalam pembelajaran bahasa Indonesia. Diantara empat keterampilan bahasa Indonesia ter- sebut, salah satu keterampilan yang menjadi sorotan utama adalah keterampilan membaca.

Membaca merupakan suatu kegiatan atau proses kognitif yang berupaya untuk menemukan berbagai informasi yang terdapat dalam tulisan. Pembelajaran membaca di Sekolah Dasar (SD) hendaklah dilaksanakan dengan proses membaca yang tepat. Rahim (2008:99) mengemukakan untuk mendorong peserta didik dapat memahami berbagai bahan bacaan, guru hendaklah menggabungkan proses membaca, yaitu prabaca, saat baca, dan pascabaca. Berarti, proses membaca bukan merupakan satusatunya tujuan dari pembelajaran membaca akan tetapi lebih menekankan pada perolehan hasil dan pemahaman setelah membaca. 
Menurut Somadayo (2011:10) membaca pemahaman merupakan proses pemerolehan makna bacaan secara aktif dengan melibatkan pengetahuan dan pengalaman yang dimiliki oleh pembaca. Hal ini berarti ada beberapa hal pokok dalam membaca pemahaman, yaitu memahami isi bacaan yang melibatkan pengetahuan dan pengalaman pembaca, proses menghubungkannya dengan isi bacaan serta bahan ajar yang digunakannya. Walaupun demikian, membaca bukanlah suatu kegiatan yang mudah untuk dilakukan melainkan perlu bimbingan melalui proses pembelajaran yang tepat.

Berdasarkan studi pendahuluan peneliti dan dokumen perangkat pembelajaran yang dimiliki oleh guru yang dilakukan pada hari Selasa tanggal 29 Maret 2016 terhadap pembelajaran membaca pemahaman untuk kelas VI SD Negeri 18 Air Tawar Selatan, ditemui beberapa permasalahan yaitu pertama, dalam pembelajaran guru belum menggunakan strategi membaca pemahaman yang benar. Hal ini terlihat dalam pembelajaran membaca, masih adanya peserta didik dalam membaca bibirnya masih komat kamit, dan tangan masih menunjuk dengan pena. Kedua, pembelajaran yang dilakukan guru belum mengacu pada proses membaca yang semestinya yaitu prabaca, saat baca dan pascabaca. Hal ini terlihat pada indikator yang terdapat pada RPP yang digunakan guru dalam pembelajaran. Ketiga, bahan ajar yang digunakan guru kurang mengarahkan peserta didik melakukan prediksi terhadap gambar dan judul bahan bacaan yang akan dibaca. Keempat, guru sudah terbiasa mengambil materi sebagai bahan ajarnya dari buku teks atau buku pelajaran yang telah disediakan sekolah sehingga belum menggambarkan proses dari membaca. Kelima, strategi yang digunakan dalam bahan ajar membaca pemahaman belum menggunakan inovasi dan strategi terbaru yang menarik minat peserta didik. Keenam, bahan ajar yang digunakan guru belum terlihat petunjuk-petunjuk yang jelas dalam menyelesaikan tugas-tugas. Hal ini berujung pada sulitnya peserta didik dalam memahami isi bacaan.

Permasalahan di atas sesuai dengan hasil penelitian oleh Ness (2011:4) menjelaskan beberapa guru belum memahami tahapan proses keterampilan membaca yang benar, padahal hal tersebut merupakan 
dasar penting dari pemahaman bacaan. Sedangkan, Harvey (2013:3) menjelaskan peserta didik hanya terfokus untuk membaca saja, namun belum bisa untuk memahami isi bacaan. Senada dengan itu, Ortlieb, (2013:23) menjelaskan(1) peserta didik kesulitan dalam membaca, (2) strategi yang digunakan guru masih kurang tepat, sehingga peserta didik kurang bersemangat dalam membaca, (3) teks yang digunakan terlalu sulit, (4) kurangnya kemauan peserta didik dalam membaca.

Berdasarkan uraian tersebut diperlukan pengembangan perangkat pembelajaran dengan menggunakan strategi yang tepat untuk keterampilan membaca pemahaman. Perangkat pembelajaran yang memuat variasi pembelajaran keterampilan membaca pemahaman yang dapat membantu peserta didik dalam memahami isi bacaan, memperoleh informasi isi teks, mendeskripsikan isi teks, menjawab pertanyaan dan menarik kesimpulan isi teks. Salah satu, strategi yang dapat digunakan untuk membaca pemahaman yaitu dengan menggunakan Graphic Organizer Plot Diagram.

Menurut Bromley (1999:66) Plot Diagram adalah Graphic Organizer yang menampilkan alur yang terarah dalam membantu pemahaman peserta didik terhadap isi teks, karena di dalam pelaksanaanya dimudahkan oleh alur Plot Diagram yaitu: mengenal isi teks, awal isi teks, inti isi teks, solusi isi teks, dan akhir isi teks. Dengan begitu, akan terbentuk pemahaman peserta didik secara keseluruhan terhadap isi bacaan.

Berdasarkan paparan di atas, peneliti bermaksud ingin melakukan penelitian dengan judul, "Pengembangan Perangkat Pembelajaran Membaca Pemahaman Menggunakan Graphic Organizer Plot Diagram untuk kelas VI Sekolah Dasar."

\section{B. Landasan Teori}

\section{Hakikat Penelitian}

\section{Pengembangan}

Penelitian pengembangan disebut juga dengan Research and Development (R\&D). Menurut Munawaroh (2014:1) penelitian pengembangan merupakan kegiatan pengumpulan, pengolahan, analisis, dan penyajian data yang dilakukan secara sistematis dan objektif yang disertai dengan kegiatan mengembangkan sebuah produk untuk memecahkan suatu persoalan yang dihadapi. 
Pendas : Jurnal IImiah Pendidikan Dasar, ISSN Cetak : 2477-2143 ISSN Online : 2548-6950 Volume II Nomor 2, Desember 2017

Hal ini sesuai dengan yang diutarakan Putra (2012:67) bahwa tujuan penelitian pengembangan mengarahkan untuk mencari kebaharuan dan keunggulan dalam rangka efektivitas, efisiensi, dan produktivitas suatu produk yang dihasilkan. Menurut Sudjana (dalam Trianto, 2007:53) dikenal tiga macam model pengembangan perangkat pembelajaran, yaitu: model DickCarey, model Four-D dan model Kemp.

\section{Hakikat Perangkat Pembelajaran}

Perangkat pembelajaran merupakan komponen perangkat dalam proses pembelajaran yang diperlukan untuk melakukan persiapan pembelajaran agar proses pembelajaran dapat tercapai dengan baik. Menurut Trianto (2007:68) bahwa terdapat beberapa komponen perangkat pembelajaran, di antaranya dapat berupa silabus, RPP, dan bahan ajar. Kemudian, kualitas perangkat pembelajaran ditentukan berdasarkan validitas (validity), praktikalitas (practicallit$y)$, dan efektivitas (effecttiveness). Perangkat pembelajaran membaca pemahaman menggunakan Graphic Organizer Plot Diagram adalah silabus, RPP, dan bahan ajar.

\section{Hakikat Membaca Pemahaman}

Pada dasarnya setiap jenis membaca adalah membaca pemahaman. Menurut Suyoto (2013:1) bahwa membaca pemahaman adalah kemampuan membaca untuk mengerti ide pokok, detail penting, dan seluruh pengertian. Pemahaman ini berkaitan erat dengan proses pembelajaran membaca yaitu: (1) kegiatan prabaca, (2) kegiatan saat baca, dan (3) kegiatan pascabaca.

\section{Graphic Organizer Plot Diagram}

Graphic Organizer merupakan representasi visual informasi dan konsep. Menurut Lupiani (2016: 65) bahwa Graphic Organizer Plot Diagram sangat penting untuk membangun pemahaman membaca dan apresiasi. Menurut Broomley (1999:66) bahwa langkah pelaksanaan Plot Diagram yaitu: (1) membaca teks, (2) membangun pemahaman terhadap Graphic Organizer Plot Diagram, (3) mendiskusikan isi teks, (4) menggunakan Graphic Organizer Plot Diagram. Dengan alur yang terdapat pada Plot Diagram akan membawa pemahaman peserta didik memahami bacaan secara utuh dan terarah. 


\section{Pembelajaran Membaca}

\section{Pemahaman Menggunakan}

\section{Graphic Organizer Plot Diagram}

Pembelajaran keterampilan membaca pemahaman menggunakan tiga tahapan yaitu: prabaca, saat baca, dan pascabaca. Langkahlangkah Graphic Organizer Plot Diagram dapat dilakukan pada tahap saat baca, dan prabaca.

\section{Metode Penelitian}

Penelitian ini merupakan penelitian pengembangan (Research and Development). Perangkat yang dikembangkan meliputi silabus, RPP, dan bahan ajar. Desain pengembangan perangkat yang dikembangkan mengikuti model 4-D (Four-D Model) yang dikemukakan oleh Thiagarajan yang terdiri dari empat tahap, yaitu Define, Design, Develop dan Disseminate. Hal-hal yang berkaitan dengan tahapan yang dijelaskan dapat dilihat pada bagan 1 berikut.

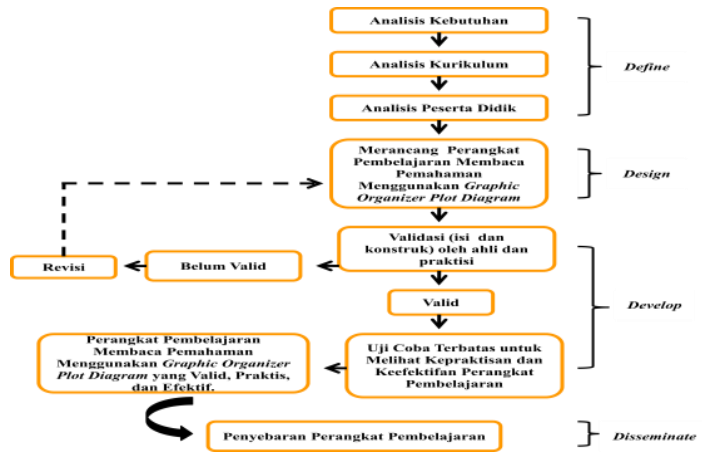

Bagan 1. Skema Pengembangan Perangkat Pembelajaran.
Pertama, define bertujuan menetapkan dan mendefinisikan syaratsyarat pembelajaran yang sesuai dengan tujuan penelitian. Meliputi : (1) Analisis Kebutuhan, antara lain: analisis silabus, RPP, dan bahan ajar dengan mengemukakan masalah dasar yang dibutuhkan dalam pengembangan perangkat pembelajaran kemudian direvisi, diperbaiki, dan dikembangkan sesuai dengan kebutuhan proses pembelajaran membaca pemahaman yang efektif di kelas VI SD. (2) Analisis kurikulum, meliputi analisis SK dan KD, konsep yang terdapat pada SK dan KD, serta tugas-tugas yang dapat dikembangkan dalam mencapai SK dan KD yang dianalisis. (3) Analisis peserta didik, merupakan telaah karakteristik peserta didik yang berhubungan dengan tingkat perkembangan bahasa yang diperoleh, keterampilan membaca, dan latar belakang pengetahuan lainnya.

Kedua, design merupakan tahap perancangan perangkat pembelajaran berdasarkan pendefinisian sebelumnya. Terdapat beberapa aspek yang perlu diperhatikan dalam merancang perangkat pembelajaran, antara lain: (a) perancangan silabus menggunakan tahapan 
proses keterampilan membaca dan Graphic Organizer Plot Diagram, (b) perancangan RPP menggunakan tahapan proses keterampilan membaca dan Graphic Organizer Plot Diagram dengan format yang disesuaikan dengan tuntutan Permendiknas No. 41 tahun 2007, (c) perancangan bahan ajar dilakukan dengan merumuskan SK dan KD serta tujuan pembelajaran kemudian diikuti dengan penyusunan materi pelajaran sesuai dengan konsepkonsep kegiatan belajar serta kesesuain penyajian bahan ajar dengan karakteristik peserta didik.

Ketiga, develop bertujuan untuk menghasilkan perangkat pembelajaran membaca pemahaman menggunakan Graphic Organizer Plot Diagram yang telah direvisi berdasarkan masukan dan hasil diskusi dengan para ahli, sehingga diperoleh perangkat pembelajaran yang valid. Jika perangkat pembelajaran sudah valid, perlu dilakukan uji coba untuk melihat praktikalitas dan efektivitas perangkat pembelajaran yang dikembangkan.

Keempat, disseminate di lakukan dalam skala terbatas yaitu uji coba pada sekolah yang lain. Hal ini bertujuan untuk melihat lebih lanjut tingkat efektivitas perangkat pembelajaran yang telah dikembangkan pada kelompok sekolah yang lain. Sehingga, keterpakaian perangkat pembelajaran yang dikembangkan tidak hanya tepat digunakan pada sekolah tertentu saja melainkan pada sekolah yang lain.

Jenis data yang diambil pada penelitian ini adalah data hasil validitas, praktikalitas, dan efektivitas. Hasil validitas diperoleh melalui penilaian validator ahli berupa validasi silabus, RPP, dan bahan ajar. Data yang diperoleh untuk praktikalitas berupa: (1) hasil pengamatan keterlaksanaan RPP dari observer, (2) hasil pengamatan aktivitas peserta didik dari observer, (3) respon peserta didik terhadap perangkat pembelajaran yang dikembangkan setelah diuji cobakan, dan (4) respon guru terhadap perangkat yang dikembangkan setelah diuji cobakan. Data validitas, praktikalitas, dan efektivitas yang diperoleh kemudian dianalisis pada setiap komponen. Untuk lebih jelasnya dapat dilihat pada jabaran berikut.

\section{Teknik Analisis Validitas}

Perhitungan data dan nilai akhir hasil validitas digunakan rumus berikut ini. 


$$
\text { Nilai Validitas }=\frac{P S}{S M} \times 100 \%
$$

Keterangan:

PS : Perolehan skor

SM : Skor maksimum

Kategori validitas silabus, RPP dan bahan ajar dengan Graphic Organizer Plot Diagram berdasarkan nilai akhir yang didapatkan dapat dilihat pada tabel 1 berikut ini:

Tabel 1. Kriteria Penetapan Tingkat

\begin{tabular}{|c|l|}
\multicolumn{2}{|c|}{ Kevalidan } \\
$\begin{array}{c}\text { Tingkat } \\
\text { Pencapaian } \\
(\%)\end{array}$ & Kategori \\
\hline $81-100$ & Sangat valid \\
$61-80$ & Valid \\
$41-60$ & Kurang valid \\
$21-40$ & Tidak valid \\
$0-20$ & Sangat tidak valid \\
\hline
\end{tabular}

\section{Teknik Analisis Praktikalitas}

Teknik analisis praktikalitas digunakan untuk analisis data hasil pengamatan keterlaksanaan RPP, angket respon guru, dan respon peserta didik. Perhitungan nilai akhir data angket dianalisis dengan menggunakan rumus dari Riduwan \& Sunarto (2007:23) yaitu sebagai berikut:

$$
N A=\frac{P S}{S M} \times 100 \%
$$

Keterangan:

NA : Nilai akhir

PS : Perolehan skor

SM : Skor maksimum
Kategori praktikalitas perangkat pembelajaran berdasarkan nilai akhir yang diperoleh bisa dilihat pada tabel 2 berikut:

Tabel 2. Kategori Kepraktisan Lembar Penilaian Respon Guru

\begin{tabular}{|c|c|}
\hline Persentase \% & Kategori \\
\hline $81-100$ & Sangat Praktis \\
$61-80$ & Praktis \\
$41-60$ & Cukup Praktis \\
$21-40$ & Kurang Praktis \\
$1-20$ & Tidak Praktis \\
\hline
\end{tabular}

\section{Analisis Data Efektivitas}

Data hasil pengisisan lembar pegamatan aktivitas peserta didik dianalisis dengan perhitungan persentase mengunakan rumus yang dikembangkan dari konsep dasar evaluasi hasil belajar (Arikunto, 2006:233) sebagai berikut.

$$
\text { Persentase }=\frac{\text { Frekuensi Aktivitas }}{\text { Jumlah Siswa }} \times 100 \%
$$

Berdasarkan persentase yang diperoleh, dilakukan pengelompokan sesuai dengan kriteria pada tabel 3 sebagai berikut.

Tabel 3. Kriteria Penetapan Aktivitas Peserta Didik

\begin{tabular}{|c|c|}
\hline Persentase \% & Kriteria aktivitas \\
\hline $81-100$ & Sangat Baik \\
$61-80$ & Baik \\
$41-60$ & Cukup Baik \\
$21-40$ & Kurang Baik \\
$1-20$ & Tidak Baik \\
\hline
\end{tabular}

\section{Hasil dan Pembahasan}

Hasil dari penelitian ini adalah pengembangan perangkat 
pembelajaran membaca pemahaman menggunakan Graphic Organizer Plot Diagram di kelas VI SD yang valid, praktis, dan efektif. Perangkat pembelajaran tersebut telah diuji cobakan pada kelas VI SDN 18 Air Tawar Selatan dengan jumlah peserta didik 29 orang serta dilakukan penyebaran dalam skala terbatas pada kelas VI SDN 03 Ikur Koto dengan jumlah peserta didik 19 orang. Untuk lebih jelasnya, dapat diuraikan sebagai berikut.

\section{Validitas Perangkat}

\section{Pembelajaran}

Validasi perangkat pembelajaran yang telah dikembangkan melibatkan 7 orang validator, yang terdiri dari 4 orang dosen sebagai ahli dan 3 orang guru sebagai praktisi. Hasil validasi dapat dilihat pada grafik 1 .

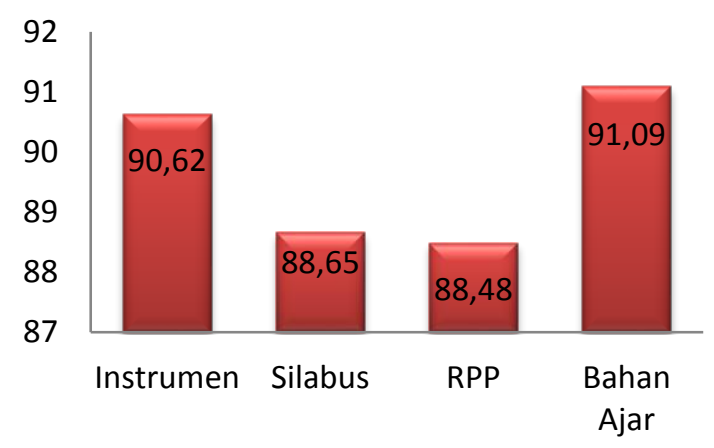

Grafik 1. Validitas Perangkat Pembelajaran

Pada Grafik 1. diperoleh hasil penilaian validitas perangkat pembelajaran oleh validator. Plomp
(2007:127) menyatakan bahwa karakteristik dari perangkat pembelajaran yang dikatakan valid apabila ia merefleksikan jiwa pengetahuan (state of the art knowledge). Hal inilah yang dikatakan dengan validasi isi (content validiy). Oleh sebab itu, validasi yang dilakukan terhadap perangkat pembelajaran ini menekankan pada validitas isi (content validity) dan validitas konstruk (construct validity).

Berdasarkan hasil validasi yang dilakukan, perangkat pembelajaran membaca pemahaman (silabus, RPP, dan bahan ajar) yang dikembangkan telah dinyatakan valid dan dapat menunjang efektivitas pembelajaran membaca pemahaman di kelas VI SD.

\section{Praktikalitas Perangkat}

\section{Pembelajaran}

Tabel 4. Hasil Uji Praktikalitas Perangkat Pembelajaran

\begin{tabular}{|c|c|c|}
\hline $\begin{array}{c}\text { Aspek } \\
\text { Praktikalitas }\end{array}$ & $\begin{array}{l}\text { Rata- } \\
\text { rata }\end{array}$ & Kategori \\
\hline $\begin{array}{l}\text { 1. Keterlaksanaan } \\
\text { RPP }\end{array}$ & $93,66 \%$ & $\begin{array}{l}\text { Sangat } \\
\text { praktis }\end{array}$ \\
\hline $\begin{array}{l}\text { 2. Hasil penilaian } \\
\text { respon guru }\end{array}$ & $98,6 \%$ & $\begin{array}{l}\text { Sangat } \\
\text { praktis }\end{array}$ \\
\hline $\begin{array}{l}\text { 3. Hasil penilaian } \\
\text { peserta didik }\end{array}$ & $91,29 \%$ & $\begin{array}{l}\text { Sangat } \\
\text { praktis }\end{array}$ \\
\hline
\end{tabular}

Berdasarkan tabel 4 di atas, Untuk melihat perangkat pembelajaran yang dikembangkan praktis atau tidak, dilakukan uji coba pada 
peserta didik kelas SDN 18 Air Tawar Selatan. Merujuk pada RPP yang telah dikembangkan, kegiatan pembelajaran dilakukan tiga kali pertemuan. Tingkat praktikalitas diamati melalui keterlaksanaan RPP, angket respon guru, angket respon peserta didik, dan hasil wawancara terhadap kemudahan penggunaan perangkat pembelajaran.

Hal ini sesuai dengan Plomp (2007:127) menjelaskan bahwa sebuah perangkat pembelajaran dikatakan praktis apabila perangkat pembelajaran dapat digunakan dengan mudah oleh guru dan peserta didik dalam proses pembelajaran.

\section{Efektivitas Perangkat}

\section{Pembelajaran}

Perangkat pembelajaran yang dinyatakan valid dan praktis sebelumnya perlu dilihat efektivitasnya dalam proses pembelajaran membaca. Kemendikbud (2013:78) menjelaskan perangkat pembelajaran dikatakan efektif apabila peserta didik melakukan aktivitas dengan kategori baik. Lebih lanjut, Abidin (2012:278) menjelaskan bahwa keterampilan membaca peserta didik dikatakan efektif apabila peserta didik memperoleh ketuntasan klasikal $\geq 75 \%$ hal ini dapat dilihat pada tabel
5 berikut.

Tabel 5. Hasil Uji Efektivitas Perangkat Pembelajaran

\begin{tabular}{|l|c|l|}
\hline \multicolumn{1}{|c|}{$\begin{array}{l}\text { Aspek } \\
\text { Efektivitas }\end{array}$} & $\begin{array}{c}\text { Rata- } \\
\text { rata }\end{array}$ & Kategori \\
\hline 1. Aktivitas & $90,88 \%$ & $\begin{array}{l}\text { Sangat } \\
\text { peserta didik } \\
\text { baik }\end{array}$ \\
2. Penilaian \\
proses \\
keterampilan \\
$\begin{array}{l}\text { membaca } \\
\text { pemahaman } \\
\text { Penilaian hasil } \\
\text { membaca } \\
\text { pemahaman }\end{array}$ & $81,83 \%$ & Tinggi \\
\hline
\end{tabular}

Berdasarkan tabel 5 di atas, efektivitas perangkat pembelajaran dapat membantu peningkatan aktivitas, dan keterampilan membaca peserta didik. Selama proses pembelajaran, peserta didik terlibat aktif melakukan sejumlah kegiatan membaca meliputi kegiatan prabaca, saat baca, dan pascabaca.

Penggunaan bahan ajar menggunakan Graphic Organizer Plot Diagram mampu meningkatkan keterampilan peserta didik dalam memahami bacaan, memberikan daya tarik, dan termotivasi peserta didik untuk belajar. Berbagai kegiatan yang dilakukan dalam pembelajaran mampu mengembangkan multiple intelegensi peserta didik. Seperti aktivitas visual activities yaitu peserta didik memperhatikan gambar. Gambar yang disajikan di bahan ajar tentunya dengan warna yang jelas sehingga 
menarik bagi peserta didik, selain itu, oral activities juga melatih peserta didik untuk mengajukan pertanyaan atau memberikan pendapat.

\section{E. Kesimpulan}

Berdasarkan hasil uji coba perangkat, analisis, dan temuantemuan penelitian maka secara umum dapat disimpulkan bahwa perangkat pembelajaran membaca pemahaman menggunakan Graphic Organizer Plot Diagram yang dikembangkan valid, praktis dan efektif.

\section{DAFTAR PUSTAKA}

\section{Buku :}

Abidin, Yunus. (2012). Pembelajaran Bahasa Berbasis Pendidikan Karakter. Bandung: Refika Aditama.

Arikunto, Suharsimi. (2006). Prosedur Penelitian: Suatu Pendekatan Praktek. Jakarta: Rineka Cipta.

Broomley, Karen, Linda Irwin De Vitis, dan Marcia Modlo. (1999). 50 Graphic Organizer for Reading, Writing, \& More. USA: Scholastic

Firman, Harry. (2000). Penilaian Hasil Belajar dalam Pengajaran. Bandung: FMIPA UPI.

Rahim, Farida. (2007). Pengajaran Membaca di Sekolah Dasar. Jakarta: Bumi Aksara.

Riduwan \& Sunarto. (2007). Pengantar Statistika. Bandung: Alfabeta.

Somadayo, Samsu. (2011). Strategi dan Teknik Pembelajaran
Membaca. Yogyakarta: Graha IImu.

Trianto. (2007). Model Pembelajaran Terpadu dalam Teori dan Praktek. Jakarta: Prestasi Pustaka.

Plomp, T. dan Nieveen, N. (Eds). (2007). An Introduction to Educational Design Research. Enschede: Netherlands Institute for Curriculum Development (SLO).

\section{Artikel in Press :}

Lupiani. (2016). Types og Graphic Organizer on Storyboard That.

\section{Jurnal :}

Harvey, Michele. 2013. Reading Comprehension: Strategies for Elementary and Secondary School Students. Lynchburg College.

Ness, Molly 2011. Explicit Reading Comprehension Instruction in Elementary Classrooms: Teacher Use of Reading Comprehension Strategies. Journal of Research in Childhood Education.

Ortlieb, Evan. 2013. Using Anticipatory Reading Guides to Improve Elementary Student's Comprehension. International Journal of Instruction. 